Jpn. J. Med. Mycol.

Vol. 38, 161-166, 1997

ISSN 0916-4804

総 説

Aspergillus 抗原とアレルギー性呼吸器疾患

\author{
秋山一男
}

国立相模原病院臨床研究部

\begin{abstract}
要旨
真菌はハウスダスト, 花粉とならんで気管支喘息, アレルギー性鼻炎等アレルギー疾患の主要な原因アレルゲンと 考えられている.

その中でもAspergillus 属は気管支喘息のみならず，アレルギー性気管支肺アスペルギルス症（ABPA）, 過敏性肺臓 炎等多彩なアレルギー性呼吸器疾患の原因アレルゲンとして知られている. 屋外空中飛散真菌相においてはAspergillus 属は最近減少する傾向にあるが, 成人喘息患者における即時型皮内反応陽性頻度では, $10 \%$ 前後でほぼ一定しており 真菌アレルゲンとしては Candida 属に続いている. 最近の家屋構造の変化に伴い屋内家塵中の真菌相として A. fumigatus 以外に A. restrictus や A. versicolor 等もアレルゲンとして重要であり, これらを原因アレルゲンとした臨床例の発見が待 たれる. ABPA の原因アレルゲンとしてはA. fumigatus が多いが, 味噌・瞫油醸造業関連の A. oryzae による ABPA は 職業病という一面もある. A. fumigatus 由来の主要アレルゲンとして mitogillin, MnSOD, PMP との相同性タンパク が示されている. 抗原分析においては今後は単に IgE抗体との反応の面からだけではなく, 臨床病態との関連での重 要なアレルゲンを解析することが必要であろう.
\end{abstract}

Key words : アスペルギルス フミガーツス (Aspergillus fumigatus), 気管支喘息 (Bronchial asthma), アレル ギー性気管支肺アスペルギルス症 (Allergic bronchopulmonary aspergillosis), アスペルギルスオ リゼ (Aspergillus oryzae), Asp $f \mathrm{I}$

はじめに

真菌はハウスダスト，花粉とならんで気管支喘息，ア レルギー性鼻炎等アレルギー疾患の主要な原因アレルゲ ンと考えられている.

成人気管支喘息に扔ける主要真菌アレルゲンとしては いわゆる真菌 5 種として, Candida, Aspergillus, Alternaria, Cladosporium, Penicillium 属が日常臨床において皮虚反応， RAST 等アレルゲン検索に用いられる.しかしながら気 管支喘息の原因アレルゲンであるとの確定診断は必ずし も容易ではない. 気管支喘息患者では，ハウスダスト， ダニや花粉等の抗原に対して即時型皮膚反応陽性者の $80 \%$ 以上に血中 IgE 抗体を認めるが, 真菌抗原につい ては一般にその陽性頻度は低い. 即時型皮膚反応陽性か つ RAST 陽性者に扔ける吸入誘発反応陽性率はさらに 低いことは日常臨床上よく経験するところである ${ }^{1)}$ 。ま た真菌のアレルゲン分析はその複雑さの故もあり, ダニ, スギのアレルゲン分析と比べて遅れて㧍り，まだその端 緒についたばかりである.

Aspergillus 属はアレルギー性呼吸器疾患の原因アレル ゲンとしては最もよく知られている真菌であり, 気管支

別刷請求先 : 秋山一男

于228 相模原市桜台 $18-1$

国立相模原病院臨床研究部
喘息のみならずアレルギー性気管支肺アスペルギルス症 (ABPA), 過敏性肺臟炎, 菌球症を引き起こす。本稿で はアレルギー性呼吸器疾患におけるAspergillus 属の関わ りを，気管支喘息，ABPAを中心に述べる。

\section{屋外空中飛散真菌相とアレルギー反応}

日常臨床検査に用いられる主要真菌アレルゲンは, 人 体常在菌であるCandida 以外は, いわゆる屋外空中飛散 真菌として頻度が高い為に通常用いられてきた. 空中飛 散真菌相における優位菌種は地方により異なるが，当院 屋上（地上 $19.5 \mathrm{~m}$ ）に押いて落下培養法で検索した空 中飛散真菌数を表 1 に示す ${ }^{2)} .1969 \sim 70$ 年においては上 記の現在皮膚テスト用抗原として鳥居薬品より発売され ている真菌 5 種が上位を占め, Aspergillus は $4.8 \%$ で 4 番 目の頻度であるが, 20 年後の 1989 年では, Cladosporium, Alternaria は以前同様 1，2 位を占めているが, Aspergillus の検出頻度は $0.5 \%$ と激減し, 代わってEpicoccum, Curvularia, Fusarium 等の検出頻度が増加してきている.

現在当院では皮虐テスト用真菌抗原として上記 5 種 抗原に加えてMucor, Botrytis, Fusarium, Cephalosporium, Cephalothecium, Epicoccum さらに皮虐糸状真菌である Trichophyton を用いている. 表 2 に1987〜1989の 3 年間 における皮虚テスト受検者（主として成人気管支喘息患 者）の真菌抗原に対する即時型皮内反応陽性率と空中飛 
Table 1. Outdoor airborne fungi in Sagamihara area (\%)

\begin{tabular}{lrllr}
\hline \multicolumn{2}{c}{$1969 \sim 70$} & & & \multicolumn{2}{c}{1989} \\
\cline { 1 - 1 } \cline { 5 - 5 } Cladosporium & 24.2 & & Cladosporium & 26.4 \\
Altermaria & 16.4 & & Alternaria & 11.8 \\
Yeasts & 7.4 & & Yeasts & 6.9 \\
Aspergillus & 4.8 & & Epicoccum & 5.6 \\
Penicillium & 3.9 & & Curvularia & 4.0 \\
Candida & 3.0 & & Arihrinium & 3.0 \\
Cephalosporium & 1.1 & & Ulocladium & 2.4 \\
Trichothecium & 0.9 & & Fusarium & 1.9 \\
Papullaria & 0.6 & & Botrytis & 1.8 \\
Sepedonium & 0.5 & & Penicillium & 1.3 \\
& & & Aspergillus & 0.5 \\
\hline
\end{tabular}

Table 2. Intradermal skin response to fungi and outdoor airborne fingi

\begin{tabular}{|c|c|c|c|c|c|c|}
\hline & \multicolumn{3}{|c|}{$\begin{array}{l}\text { Positive ratio of immediate } \\
\text { intradermal skin response (\%) }\end{array}$} & \multicolumn{3}{|c|}{$\begin{array}{c}\text { Outdoor airborne fungi } \\
\text { (colonies) }\end{array}$} \\
\hline & 1987 & 1988 & 1989 & 1987 & 1988 & 1989 \\
\hline Candida & 35.2 & 41.3 & 35.3 & & & \\
\hline Aspergillus & 11.1 & 10.5 & 10.6 & 13 & 8 & 10 \\
\hline Alternaria & 6.8 & 9.1 & 19.0 & 982 & 433 & 247 \\
\hline Fusarium & 6.3 & 4.1 & 7.4 & 41 & 50 & 3 \\
\hline Trichophyton & 5.7 & 4.3 & 8.3 & & & \\
\hline Penicillium & 5.4 & 5.1 & 10.7 & 61 & 54 & 27 \\
\hline Cladosporium & 4.4 & 4.3 & 6.8 & 946 & 362 & 554 \\
\hline Mucor & 3.5 & 1.3 & 2.8 & 2 & 5 & 3 \\
\hline Caphalosporium & 3.3 & 2.4 & 5.2 & & & \\
\hline Cephalothecium & 1.7 & 1.6 & 1.9 & & & \\
\hline Botrytis & 1.2 & 1.3 & 1.7 & 33 & 33 & 37 \\
\hline Epicoccum & - & 0.6 & 1.2 & 177 & 66 & 177 \\
\hline
\end{tabular}

散真菌数とを対比して示す. 真菌以外の抗原に対する即 時型皮内反応陽性率は，八ウスダスト，ダニに対して 60 $\sim 70 \%$ ，スギが約 $50 \%$, 以下ブタクサ, カモガヤ，ヒ メガマ等の花粉抗原に対して $20 \sim 30 \%$ であり，従って Candida は全体で 4 位, Aspergillus, Alternaria は 10 位前後 の陽性頻度である.

この表で興味深い点は, 空中飛散真菌数として多数を 占めるCladosporium, Alternaria, Epicoccum に対する即時 型皮内反応陽性率が必ずしも高くはなく, 空中飛散真菌 数としては少ないあるいは減少傾向にあるAspergillus, Fusarium, Penicillium に対する陽性率が相対的に高い点 である. 即ち, 暴露抗原量と皮虐反応との結果が相関し ない. この点は一般にスギやブタクサ等の花粉抗原やダ 二に対する皮膚反応陽性率は暴露抗原量と相関すること を考えると真菌アレルギーの特殊性として興味深い問題 である 1)。また人体内常在真菌であるCandida や皮虐系 状真菌である Trichophyton に対する反応が，各々 35〜40 \%, 4〜8\%と高い事実は他の吸入性抗原と感作経路が 異なる可能性を考えると非常に興味深い.

図 1 には当院において過去約 20 年間に実施した成人 気管支喘息患者約 8,500 名に対する主要抗原による即時

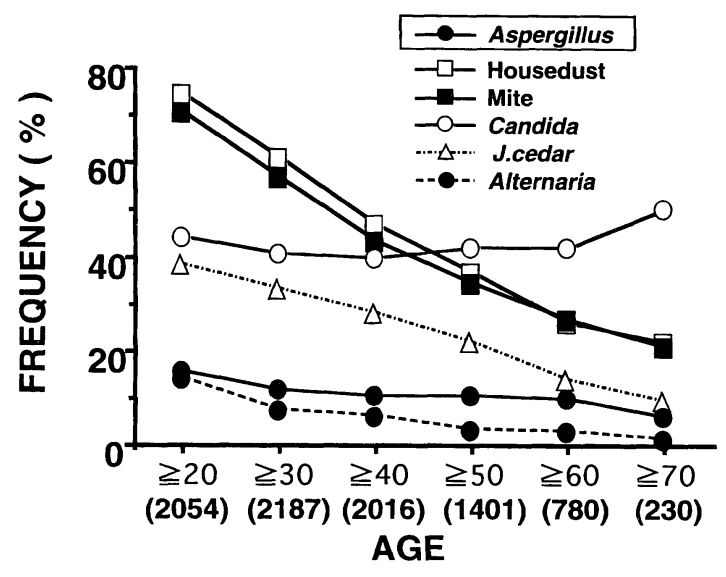

Fig. 1. Immediate skin reaction

型皮内反応の陽性率を受検者の年代別に示している。 八 ウスダスト，ダニ，スギ，及び真菌でも典型的なアトピー 型抗原と考えられているAlternaria では陽性率は若年者 で高く, 年齢と共に低下していく傾向にある. 一方, Candida は年代による陽性率の変化はなく, どの年代でも 40 $\%$ 以上の陽性率を示し, 特に50歳以降では八ウスダス トやダニを抜いて即時型反応陽性率が最も高くなる ${ }^{3)}$. すなわち人体常在真菌である Candida に対する即時型皮 膚アレルギー反応は, そのほかの吸入性真菌抗原に対す る反応とは異なるようである.Aspergillus に対する反応 は両者の中間に位置するように見られるが，これら真菌 による病態の違いを考えると非常に興味深い.

前述したように真菌即時型皮膚反応陽性者における血 中 IgE 抗体陽性頻度は夕゙ニ, 花粉等に比べると低いこと が知られているが，当院における気管支喘息患者の内, 皮膚反応で真菌抗原に即時型陽性を示した患者 100 名 のそれぞれの真菌抗原に対する血中 IgE 抗体の陽性率 は, Candida で $35 \%$, Alternaria, Cladosporium が $31 \%$ で, Aspergillus は Penicillium と同様 $25 \%$ 前後と陽性率は真菌 以外の抗原と比べると明らかに低い。この原因としては， (1)真菌皮虐反応では非特異的反応が多い, (2) IgE 以外の 抗体が関与している可能性がある，(3) RASTのような in vitro 検查では，その行程中に low affinity の抗体は消 失してしまう可能性がある一などが考えられるが，未だ 不明である.また，使用する抗原の側の問題として，周 知のように真菌は培養方法により分泌される物質等が異 なることが知られているが, 各種検查に用いられる抗原 の標準化がされていないため, 使用する抗原により抗原 性が異なる可能性がある.ささらには, 真菌抗原間の交叉 抗原性の存在等もあり，検討すべき課題は多い.

また最近は家屋構造の変化, 屋内生活時間の延長等に より屋内環境中のアレルゲンの関与が問題となっている. 真菌アレルゲンに抒いてもAspergillus 属では, これまで に研究されているA. fumigatus に加えて, A. restrictus, A. versicolor が家塵中から培養され, かつアレルギー疾患患 者での皮内反応や血中 IgE 抗体陽性頻度の点で今後注目 しなければならないアレルゲンと考えられている ${ }^{4,5)}$. 
アレルギー性気管支肺アスペルギールス症

ABPA は 1952 年 Hinsonらにより bronchopulmonary aspergillosis として初例が報告されて以来すでに 40 年近 く経過し，また本邦でも 1972 年に加藤らにより初例が 報告されて以来, 今日では, アレルギー科医のみならず, すでに一般の医師にもよく知られた疾患となってきた. 本症は好酸球増多と肺浸潤がみられ PIE (pulmonary infiltration with eosinophilia) 症候群の代表的疾患であ り, Crofton らの分類で第 3 群 pulmonary eosinophilia with asthmaに属する. Aspergillus がアトピー素因を持つ 気管支喘息患者の気管支に持続的に腐生して発症する Gell and Coombs のI 型プラスII型（あるいはIV型）ア レルギーの代表的疾患と言われてはいるが，しかしなが ら，未だ発症のメカニズムは解明されてはいない. ABPA の原因真菌としてはA. fumigatus がほとんどであるが, 他の Aspergillus 属によるABPA も報告されており，われ われもA. niger およびA. oryzaeによる本症を経験してい る. 特に $A$. oryzae は本邦においては味増, 滰油製造のた めの敖かびとして使用されており，本菌による ABPA は職業病としての側面も持っている ${ }^{6)}$ 。また，最近は Aspergillus 属以外の真菌, Candida albicans, Penicillium, Stemphylium languinosum, Curuvularia lunata, Drechslera hawaiiensis, Helminthosporium, Torulopsis glabrata, Mucor 類似真菌等による同様の疾患の発症も報告されており, 最近はこれらをまとめてアレルギー性気管支肺真菌症 (ABPM : allergic bronchopulmonary mycosis) と呼んで いる.

Aspergillus 胞子は直径 $2 \sim 3.5 \mu \mathrm{m}$ で吸入されると中枢 気管支などに捕捉されやすく気道粘膜上に付着, コロニー 形成しまた体温が至適発育温度（30〜 $35{ }^{\circ} \mathrm{C} ）$ に近いた め気管支腔内で腐生，増殖が進行すると考えられる．本 症の発症機序はまだ不明の点が多いが，Aspergillus 抗原 に対する IgE 抗体および IgG 抗体が関与する，いわゆる
I 型及び皿型アレルギーが本症発症に関係することを示 す報告は多い.アトピー素因のある宿主にAspergillus が 持続的に腐生，増殖することにより $\mathrm{IgE}$ 抗体のみならず $\operatorname{IgG}, \operatorname{IgA}, \operatorname{IgM}$ 各クラス抗体が産生 ${ }^{7)}$ され抗原一抗体複 合物の形成をみることにより III型アレルギーが引き起こ されると考えられる（図 2). 抗 Aspergillus $\operatorname{IgE}$ 抗体によ り感作されたマスト細胞はAspergillus 抗原と反応して種々 化学物質を放出し気管支平滑筋の攣縮，気道粘膜透過性 六進，好酸球浸潤さらに好酸球からの種々化学物質の遊 離をきたし組織障害を引き起こす 8$)$.これらの反応がさ らにAspergillus の気管支内持続腐生に好条件となり悪循 環が進行して気管支壁の破壊が進行して気管支拡張症を 引き起こすと考えられる.また，抗 Aspergillus IgA 抗体 も本症の肺障害に関与している可能性も指摘されている. 肺病変内の肉芽腫様変化, $\mathrm{T}$ 細胞の増加, 気道への単核 球浸潤，さらにはAspergillus 抗原による患者リンパ球の 幼若化など細胞性免疫，すなわち IV 型アレルギーの関与 を示唆する成績や, Aspergillus 自身が直接補体系を活性 化して組織障害を起こすという説もある.

\section{Aspergillus と Alternaria の抗原性}

ABPA をはじめとするABPMについて真菌アレルギー という観点からみて興味深いことは，Aspergillusによる ABPM はすでに多数の報告がみられるが，アトピー性 真菌抗原としてはAspergillus と同等あるいはそれ以上に 重要と考えられる AlternariaによるABPMすなわちアレ ルギー性気管支肺アルテルナリア症の報告が著者の知る 範囲ではほとんどみられないことである.Aspergillusに よるアレルギー関連呼吸器疾患としては，気管支喘息， ABPM，過敏性肺炎，菌球症等が報告されているが， Alternariaによるアレルギー呼吸器疾患としては気管支 喘息の他には過敏性肺炎の原因として少数ながら報告さ れているのみである. Patterson らはABPAを経過から 5 期に分類し，ABPA に唯一特異的である中枢性気管支拡



Fig. 2. Clinical course and change of anti- Aspergillus antibody titer 
Table 3. S-ABPA spergillosis and S-ABPA lternariosis among asthma patients

\begin{tabular}{|c|c|c|}
\hline & Aspergillus & Alternaria \\
\hline No. of patients tested by skin test & $664($ BA 474) & 702 (BA 509) \\
\hline No. of positive ISR & 84（BA 72） & $64($ BA 50$)$ \\
\hline $\begin{array}{l}\text { No. of patients tested with serum } \\
\text { antibody }\end{array}$ & 78 (BA 68) & $59\left(\begin{array}{ll}\text { BA } & 47\end{array}\right)$ \\
\hline IgE antibody & $+14($ BA 10$)$ & $+24($ BA 17$)$ \\
\hline Precipitin antibody & -7 & +17 \\
\hline IgG antibody & $\begin{array}{ccc}+7 & +3 & -4 \\
(\text { BA } 6) & (\text { BA 2) } & (\text { BA 2) }\end{array}$ & $\begin{array}{cccc}+12 & -5 & +2 & -5 \\
(\text { BA } 11) & (\text { BA } 1) & (\text { BA } 2) & (\text { BA } 3)\end{array}$ \\
\hline $\mathrm{S}-\operatorname{IgE}>300 \mathrm{U} / \mathrm{m} l$ & $\begin{array}{l}6(0.9 \% 6 / 664) \\
{[\text { BA } 5: 1.05 \%(5 / 474)]}\end{array}$ & $\begin{array}{l}10(1.4 \% 10 / 702) \\
{[\text { BA } 10: 1.96 \%(10 / 509)]}\end{array}$ \\
\hline
\end{tabular}

BA : Bronchial asthma ISR : Immediate Skin Response

Table 4. A. fumigatus related allergen/antigen (ABPA)

\begin{tabular}{|c|c|c|c|c|c|c|}
\hline \multicolumn{2}{|c|}{ ALLERGEN } & ORIGIN & CHARACTERISTICS & ALLERGEN & ORIGIN & CHARACTERISTICS \\
\hline \multicolumn{2}{|c|}{ 70-kD PROTEIN ${ }^{1)}$} & HYPHAE & $\begin{array}{l}\text { IgE, IgG BINDING ACTIVITY } \\
\text { ABPA }\end{array}$ & $\begin{array}{l}\text { Asp f I (18-kD PROTEIN })^{8,9)} \\
\text { rAsp f I / }{ }^{10)}\end{array}$ & HYPHAE & $\begin{array}{l}\text { IgE BINDING ACTIVITY; } \\
\text { mitogillin family same as } \mathrm{Ag} 3 \text { ? } \\
\text { ABPA, BA }\end{array}$ \\
\hline \multicolumn{2}{|c|}{$\begin{array}{l}\text { 35-kD, 65kD GLYCOPRO- } \\
\text { TEIN }^{2}\end{array}$} & HYPHAE & $\begin{array}{l}\text { IgE, IgG BINDING ACTIVITY; } \\
\text { Con A BINDING ACTIVITY } \\
\text { ABPA, aspergilloma }\end{array}$ & $\begin{array}{l}\text { gp } 55(55-k D \text { GLYCOPRO- } \\
\text { TEIN })^{11)}\end{array}$ & HYPHAE & $\begin{array}{l}\text { IgE, BINDING ACTIVITY; } \\
\text { protease activity }[-]\end{array}$ \\
\hline \multicolumn{2}{|c|}{ Ag $3(24-k D \text { PROTEIN })^{3,7)}$} & HYPHAE & $\begin{array}{l}\text { IgE, IgG BINDING ACTIVITY } \\
\text { (precipitin }[-] \text { ) Con A BINDING } \\
\text { ACTIVITY }(-) \text {, HEAT LABILE } \\
\text { ABPA }\end{array}$ & 65-kD PROTEIN ${ }^{12)}$ & HYPHAE & $\begin{array}{l}\text { IgE, IgG BINDING ACTIVITY; } \\
\text { heat shock protein family } \\
\text { ABPA }\end{array}$ \\
\hline \multicolumn{2}{|c|}{$\operatorname{Ag} 5(35-k D \text { PROTEIN })^{6,7)}$} & SPORE & $\begin{array}{l}\text { IgE, IgG BINDING ACTIVITY; } \\
\text { Con A BINDING ACTIVITY }(-) \text {, } \\
\text { HEAT LABILE } \\
\text { ABPA }\end{array}$ & $\begin{array}{l}\text { gp66 (66-kD GLYCOPRO- } \\
\text { TEIN })^{13)}\end{array}$ & HYPHAE & $\begin{array}{l}\text { IgE BINDING ACTIVITY; } \\
\text { subunit of Ag } 7 \text { ? } \\
\text { ABPA, CF }\end{array}$ \\
\hline \multicolumn{2}{|c|}{$\begin{array}{l}\text { Ag } 7(150-200-k D \text { GLYCOPRO- } \\
\text { TEIN } 35-k D \text { SUBUNIT })^{4,7)}\end{array}$} & HYPHAE & $\begin{array}{l}\text { IgE, IgG BINDING ACTIVITY; } \\
\text { Con A BINDING ACTIVITY, } \\
\text { HEAT STABLE } \\
\text { ABPA }\end{array}$ & 26.7kD PROTEIN ${ }^{14)}$ & & $\begin{array}{l}\text { IgE BINDING ACTIVITY; } \\
\text { MnSOD (manganese superoxide } \\
\text { dismutase); human } \\
\text { MnSOD and } 67.2 \% \text { homology } \\
\text { ABPA, BA }\end{array}$ \\
\hline \multicolumn{2}{|c|}{$\begin{array}{l}\text { Ag } 13(70-\mathrm{kD} \text { GLY } \\
\text { TEIN })^{5,7)}\end{array}$} & HYPHAE & $\begin{array}{l}\text { IgG BINDING ACTIVITY; } \\
\text { Con A BINDING ACTIVITY, } \\
\text { HEAT LABILE } \\
\text { antigen C; chymotryptic activity[+] } \\
\text { ABPA }\end{array}$ & rAsp fIII (21-kD PROTEIN $)^{15)}$ & & $\begin{array}{l}\text { IgE BINDING ACTIVITY; } \\
\text { PMP of Candida boidinii } \\
\text { (peroxisomal membrane proteins) } \\
\text { and } 48 \% \text { homology } \\
\text { Asp pts. }\end{array}$ \\
\hline \multicolumn{4}{|c|}{ 1) Leung, PSC., Gershwin, ME., et al. : Int Arch Allergy Appl } & \multicolumn{3}{|c|}{$\begin{array}{l}\text { 8) Arruda, LK., Platts-Mills, TAE., et al. : J Exp Med } 1990 \\
172: 1529-1532\end{array}$} \\
\hline \multicolumn{4}{|c|}{$\begin{array}{l}\text { 2) Kurup, VP., Ramasamy, M., et al. : Int Arch Allergy Appl } \\
\text { Immunol } 1988: 86: 176-182\end{array}$} & \multicolumn{3}{|c|}{$\begin{array}{l}\text { 9) Arruda, LK., Mann, BJ., Chapman, MD.: J Immunol 1992: } \\
149: 3354-3359\end{array}$} \\
\hline \multicolumn{4}{|c|}{ 3) Longbottom, JL. : J Allergy Clin Immunol $1986: 78: 18-24$} & \multicolumn{3}{|r|}{ : J Immunol $1992: 149:$} \\
\hline \multicolumn{4}{|c|}{$\begin{array}{l}\text { 4) Harvey, C., Longbottom, JL. : Clin exp Immunol } 1986: 65 \text { : } \\
206^{-214}\end{array}$} & \multicolumn{3}{|c|}{$\begin{array}{l}\text { 11) Teshima, R., Ikebuchi, H., et al. : J Allergy Clin Immunol } \\
1993: 92: 698-706\end{array}$} \\
\hline \multicolumn{4}{|c|}{ 5) Harvey, C., Longbottom, JL. : Clin exp Immunol 1987: 70 : } & \multicolumn{3}{|c|}{$\begin{array}{l}\text { 12) Kumar, A., Reddy, LV., et al. : J Allergy Clin Immunol G } \\
1993: 91: 1024-1030\end{array}$} \\
\hline \multicolumn{4}{|c|}{$\begin{array}{l}\text { 6) Taylor, LM., Longbottom, JL.: J Allergy Clin Immunol 1988: } \\
81: 548-557\end{array}$} & \multicolumn{3}{|c|}{$\begin{array}{l}\text { 13) Little, SA., Wamer, JO. : J Allergy Clin Immunol } 1996: 98 \text { : } \\
\text { 55-63 }\end{array}$} \\
\hline & $\begin{array}{l}\text { 7) Longbottom, JL. } \\
\text { Immunol } 1989:\end{array}$ & $\begin{array}{l}\text { Harvey, C. } \\
38: 185^{-186}\end{array}$ & et al. : Int Arch Allergy Appl & \multicolumn{3}{|c|}{$\begin{array}{l}\text { 14) Crameli, R., Faith, A., et al. : J Exp Med } 1996: 184: 265- \\
270\end{array}$} \\
\hline & & & & $\begin{array}{l}\text { 15) Hemmann, S. } \\
\text { ECACI ' } 96\end{array}$ &. Blaser, R., & Crameli, R.: Abstract : P 452, \\
\hline
\end{tabular}

張症が出現する以前に，血中総 IgE 值が高值でAspergillus 抗原に対する即時型皮膚反応陽性の気管支喘息患者の中 で血清学的に抗 Aspergillus IgE, IgG および沈降抗体が 陽性である患者を seropositive-ABPA（S-ABPA）とし て早期発見，早期治療の必要性を唱えている ${ }^{9)}$ 。そこで，
なぜ ABPAspergillosis があるのに ABPAlternariosis が見 られないかを，その抗原性の点から検討すべく気管支喘 息患者における S-ABPAspergillosis と S-ABPAlternariosis を検索した ${ }^{10)}$. 対象は 1 年間の当院での皮膚テスト受 検者である（表 3 , カッコ内は気管支喘息患者数: 両抗 
原で母数が異なるのは検索年度が異なるため). S-ABPAspergillosis は皮膚テスト受検気管支喘息患者 474 名中 5 名で $1.05 \%$, S-ABPAlternariosis は同様気管支喘息患者 509 名中 10 名で $1.96 \%$ であった。この表からもわかる ように抗原性としてはAlternaria のほうが強いと考えら れた. 従って, 抗原性の点からは上記の疑問を説明でき ない. 両真菌の胞子のサイズの違いが影響している可能 性は考えられるが, 真菌アレルギーを考える上で興味あ る問題である.

\section{真菌アレルゲンの研究}

真菌アレルゲンの抗原分析の研究は前述したようにダ 二, 花粉に比べると遅れていると言わざるを得ない. 真 菌は生育条件, 培養条件により非常に変異しやすいこと が知られている. また, 培養条件により分泌される酵素 などの代謝産物も異なる.これらのどの成分がアレルゲ ンとして最も重要なのかについては未だ不明である. 現 在までに真菌の抗原分析の報告が少なからず出されてい るが, 多くは胞子や菌糸など菌体構成成分についての分 析が主である。また，血中 IgE 抗体との反応性（陽性頻 度, 強さ）の観点のみからの検討がほとんどであり直接 に気管支喘息発症との関わりを検討した研究は少ない. A. fumigatusに対する IgE 抗体陽性血清を用いた抗原分 析については表 4 のような報告がこれまでに見られる が, major allergenとして現在までに WHO 命名法に記 載されているのは, Asp $f \mathrm{I}, A s p f \amalg$ のみである.Asp $f$ $\mathrm{I}$ は分子量 $18 \mathrm{kD}$ で $\alpha$-sarcin, mitogillin, restrictocin な どの ribotoxin との関連が示唆されており，約 $85 \%$ の ABPA 患者血清中の IgE 抗体と反応するという.

また生物学的活性という点からの検討では human MnSOD (manganese superoxide dismutase) や Candida boidinii の PMP (peroxisomal membrane proteins) との homology を示す最近の報告もある. 今後は単に IgE 抗 体との反応の面からではなく臨床病態との関連での重 要なアレルゲンを明らかにすることが必要であると考え る.

$$
\text { ま と め }
$$

1.Aspergillus 属はアレルギー性呼吸器疾患の原因アレ ルゲンとして重要である.
2. A. fumigatus のみならず A. restrictus, A. versicolor 等も アレルゲンとなる.

3.A. oryzae は職業（病）関連としてのABPAの原因 アレルゲンとなりうる.

4.A. fumigatus 由来の主要アレルゲンとして mitogillin, $\mathrm{MnSOD}, \mathrm{PMP}$ との相同性タンパクが示されている.

\section{今後の研究の課題, 問題点}

1. 多彩なアレルギー性呼吸器疾患の原因アレルゲン／ 抗原としての A. fumigatus アレルゲンの抗原分析

2. A. restrictus, A. versicolor による臨床例の発見

3. ABPA の病態, 発症機序の解明

\section{参考文献}

1）秋山一男: 真菌に対するアレルギー反応の多様性. アレ ルギー 39 :203 (抄録), 1990.

2）信太隆夫他: 我が国の空中飛散真菌. 第 2 報 $1978 \sim 80$ 年の全国分布および 1983〜86 年の相模原市における推 移. 医療 $42: 521-529,1988$.

3）秋山一男他: アレルギー反応から見た高齢者気管支喘息 の特徵, アレルギー 43:9-15, 1994.

4）坂本龍雄, 伊藤浩明, 山田政功ほか: Aspergillus restrictus のアレルゲンとしての意義ーAspergillus fumigatus との共 通アレルゲン性に関する検討一. アレルギー 40: 13201326, 1991.

5）秋山一男他 : 家庭内環境中の真菌のアレルゲンとしての 意義. 公害健康被害補償予防協会委託業務報告書. 家庭 環境の整備に関する調査報告書 pp69-78, 日本環境衛生 センター 1993.

6) Akíyama $\mathrm{K}$ et al. : Allergic bronchopulmonary aspergillosis due to Aspergillus oryzae. Chest $91: 285-286,1987$.

7）秋山一男他:アレルギー性気管支肺アスペルギルス症の 免疫学的研究一血清総 $\operatorname{IgE}$ 值, $\operatorname{IgE}, \operatorname{IgG}, \lg A, \operatorname{IgM}$ 抗体 価と臨床経過との関連一. 日胸疾会誌 $17: 250-258,1979$.

8) Slavin RG et al.: A pathologic study of allergic bronchopulmonary aspergillosis. J Allergy Clin Immunol 81 : 718-724, 1988.

9) Greenberger PA, Patterson R: Allergic bronchopulmonary aspergillosis and the evaluation of the patient with asthma. J Allergy Clin Immunol 81 : 646-650, 1988.

10）秋山一男, 安枝 浩, 前田裕二ほか : Serological-ABPA の頻度.アレルギー $38: 209$ (抄録), 1989. 


\title{
Aspergillus Antigen and Allergic Pulmonary Diseases
}

\author{
Kazuo Akiyama \\ Clinical Research Center for Allergy and Rheumatology, National Sagamihara Hospital \\ 18-1 Sakuradai, Sagamihara, Kanagawa 228
}

Genus Aspergillus is an important causative allergen/antigen of a variety of allergic pulmonary diseases such as bronchial asthma, allergic bronchopulmonary aspergillosis and hypersensitivity pneumonitis. Not only $A$. fumigatus but also $A$. restrictus and $A$. versicolor have been cultivated from housedust and shown to sensitize humans so that they produce $\operatorname{IgE}$ antibody. A. fumigatus is known as the most common causative allergen/antigen of allergic bronchopulmonary aspergillosis (ABPA). In Japan $A$. oryzae is also an important causative allergen/antigen of ABPA as it affects workers in factories of soybean product such as soysauce and soybean paste. Homology to the mitogillin family, manganese superoxide dismutase and peroxisomal membrane proteins have been reported as major allergens of $A$. fumigatus. 